\title{
Short communication: Associations between blood fatty acids, $\beta$-hydroxybutyrate, and $\alpha$-tocopherol in the periparturient period in dairy cows: An observational study
}

\author{
A. Pilotto, ${ }^{*}$ G. Savoini, ${ }^{*}$ A. Baldi, ${ }^{*}$ G. Invernizzi, ${ }^{*}$ C. De Vecchi, $\dagger$ G. Theodorou, $\ddagger$ P. Koutsouli, $\ddagger$ and I. Politis $~^{1}$ \\ *Department of Health, Animal Science and Food Safety, University of Milan, 20133, Italy \\ †ATS (Agenzia tutela della Salute, Health Care Agency), Milan, 20122, Italy \\ ‡Department of Animal Science and Aquaculture, Agricultural University of Athens, 11855, Greece
}

\begin{abstract}
The objective of the present study was to examine the relationships between blood concentrations of fatty acids, $\beta$-hydroxybutyrate (BHB), and $\alpha$-tocopherol during the periparturient period in dairy cows. Blood samples were collected from 131 cows belonging to 4 different commercial dairy farms in southeastern Europe (Greece and Italy). We determined blood concentrations of fatty acids, BHB, and $\alpha$-tocopherol at dry-off, at calving, and $30 \mathrm{~d}$ postpartum. Results indicated that fatty acid concentrations were low at dry-off, reached maximum value at calving, and then declined at $30 \mathrm{~d}$ postpartum. In fact, fatty acid concentrations at $30 \mathrm{~d}$ postpartum were $50 \%$ lower than at calving. In contrast, BHB concentrations were low at dry-off, increased by $27 \%$ at calving, and continued to increase by another $20 \%$ at $30 \mathrm{~d}$ postpartum. Overall, we found a weak correlation between fatty acids and BHB throughout the periparturient period. Concentrations of $\alpha$-tocopherol were lowest at calving, and we detected no differences in $\alpha$-tocopherol concentrations at dry-off or $30 \mathrm{~d}$ postpartum. Negative correlations between fatty acids and $\alpha$-tocopherol were highly significant at $30 \mathrm{~d}$ postpartum and approached the level of significance at dry-off. However, both correlations became nonsignificant following the adjustment of $\alpha$-tocopherol with cholesterol, indicating that the correlations were a reflection of changes in lipid transport. We found significant negative correlations (strong at dry-off and weak at $30 \mathrm{~d}$ postpartum) between BHB and $\alpha$-tocopherol after adjustment with cholesterol. The physiological basis for the negative correlations between BHB and $\alpha$-tocopherol, especially that at dryoff, is not known and should not be taken to imply a cause-effect relationship. However, it opens the door to
\end{abstract}

Received January 24, 2016.

Accepted April 13, 2016.

${ }^{1}$ Corresponding author: i.politis@aua.gr investigating the effects of vitamin $\mathrm{E}$ on liver function in dairy cows.

Key words: $\alpha$-tocopherol, fatty acids, $\beta$-hydroxybutyrate

\section{Short Communication}

The multitude of disorders that dairy cows face during transition from the dry period to lactation is striking. At this time, milk production is high, but a lag in feed intake creates a negative energy balance. It is well documented that when the negative energy balance in the periparturient period becomes severe, the risk for several postpartum diseases increases. These include retained placenta, milk fever, metritis, mastitis, clinical ketosis, and displaced abomasum (Duffield et al., 2009; LeBlanc, 2010; Suthar et al., 2013).

Fatty acids and BHB are both used as markers of negative energy balance during the periparturient period (Konigsson et al., 2008; Ospina et al., 2010a,b; Chapinal et al., 2011; McArt et al., 2012, 2013), but in most studies, the 2 markers are presented together. More recently, McCarthy et al. (2015) showed that the concentrations of fatty acids and BHB are not well correlated during the transition period. More specifically, fatty acid concentrations increased gradually, starting before parturition and up to $9 \mathrm{~d}$ after parturition, and then gradually declined. In contrast, BHB concentrations began to increase in the late prepartum period, continued to increase during the first week postpartum, and remained elevated through $21 \mathrm{~d}$ postpartum. All correlations between fatty acids and BHB in the transition period were weak or extremely weak. McCarthy et al. (2015) concluded that changes in fatty acids and BHB concentrations should be interpreted with caution, and that changes in the concentration of one metabolite should not be taken to suggest corresponding changes in the concentration of the other.

The role of inflammation in metabolic disorders associated with transition from the dry period to lactation is not known with certainty. Bradford et al. (2015) 
have suggested that all cows experience some degree of systemic inflammation during the first 2 weeks postpartum, but the magnitude and the duration of the inflammatory state vary widely among cows. Bertoni et al. (2015) suggested that early postpartum inflammation can impair cow performance by lowering milk production, DMI, fertility, and energy efficiency. They proposed that providing appropriate nutrients such as antioxidants, n-3 (omega-3) polyunsaturated fatty acids, and vitamin D might be a way of reducing inflammation and avoiding associated conditions, such as tissue damage and digestive or metabolic syndrome-related disorders.

Vitamin $\mathrm{E}$ is one of the main antioxidant vitamins. Politis (2012) has demonstrated that vitamin E status has a direct influence on reducing the frequency of mastitis and retained placenta. Lower serum $\alpha$-tocopherol (vitamin E) concentrations are a potential early indicator for the development of left displaced abomasum in multiparous cows (Qu et al., 2013). No study has ever suggested a direct relationship between vitamin $\mathrm{E}$ and ketosis. However, in rodent models, antioxidants can improve the metabolic function of the liver, as well as immunity (Sakaguchi and Furusawa, 2006; Mao et al., 2010). Furthermore, vitamin E improves metabolic function in humans with nonalcoholic fatty liver disease (Rinella, 2015; Sato et al., 2015). Bouwstra et al. (2008) reported that vitamin E supplementation in heifers during the periparturient period reduced oxidative damage in the liver. Because information is limited concerning the relationship between indicators of negative energy balance and $\alpha$-tocopherol, the objectives of the present study were (1) to determine the relationship between fatty acids and BHB during the periparturient period in dairy cows in farms located in southeastern Europe, where cows are likely to encounter less oxidative stress than cows in North America; and (2) to examine the relationship between blood concentrations of fatty acids, $\mathrm{BHB}$, and $\alpha$-tocopherol during the periparturient period.

A total of 131 Holstein cows from 4 commercial farms participated in an observational field study. Two of the farms were in Italy and the other 2 were in Greece. Of the total, 59 cows belonged to the Italian farms (30 and 29 from each farm) and 72 belonged to the Greek farms (36 from each farm). Diets (DM basis) on the 2 Greek farms during the dry period were $42 \%$ corn silage, $40 \%$ straw hay, $9.6 \%$ soybean meal, and $8.4 \%$ molasses. After calving, the diet was $48.5 \%$ corn silage, $16.5 \%$ soybean meal, $14 \%$ alfalfa hay, $12 \%$ corn, $3.7 \%$ molasses, $1.7 \%$ rumen-protected fat, and $3.5 \%$ vitamin and mineral premix. Diets on the Italian farms during the dry period were $43.3 \%$ corn silage, $35 \%$ straw hay, $12.8 \%$ soybean meal, $5.9 \%$ corn meal, and $3 \%$ vitamin and mineral premix. After calving, the diet was $23.8 \%$ corn silage, $22.8 \%$ corn, $17.6 \%$ soybean meal, $13.5 \%$ meadow silage, $7.6 \%$ meadow hay, $5.8 \%$ alfalfa hay, $2 \%$ molasses, $1.9 \%$ extruded flaxseed, $1.5 \%$ rumen-protected fat, and $3.5 \%$ vitamin and mineral premix.

We collected blood samples from all cows at dryoff, at calving, and at $30 \mathrm{~d}$ postpartum. Serum was obtained following centrifugation of the blood samples, and it was frozen at $-80^{\circ} \mathrm{C}$ until analysis. We assayed $\alpha$-tocopherol levels using reversed-phase HPLC (C18 column, reversed-phase) with UV absorbance detection at $292 \mathrm{~nm}$, as described by Baldi et al. (2000). The extraction phase involved precipitation of plasma proteins with absolute ethanol and liquid-liquid extraction performed with hexane in the presence of butylated hydroxytoluene as a preservative. After centrifugation, the supernatant was evaporated to dryness under a stream of nitrogen, and the residue was dissolved in organic solvents; $50 \mu \mathrm{L}$ were injected directly onto the HPLC column. Samples were maintained in ice and kept in the dark during the procedure. We prepared standard solutions from a stock solution $(100 \mathrm{mg} / 10$ $\mathrm{mL}$ ) of pure DL- $\alpha$-tocopherol dissolved in methanol/ butylated hydroxytoluene. Separation was performed on the SupelcoSil LC-18 $(25 \mathrm{~cm} \times 4.6 \mathrm{~mm}, 5 \mu \mathrm{m})$ column. The mobile phase consisted of methanol:water 97:3 (vol:vol \%) pumped at a flow rate of $1 \mathrm{~mL} / \mathrm{min}$ at room temperature.

We used enzymatic colorimetric methods to determine plasma concentrations of fatty acids and BHB (Stella et al., 2007; Konigsson et al., 2008). Blood fatty acid concentrations were determined using the acyl-CoA synthetase-acyl-CoA oxidase method (Wako Chemicals, Richmond, VA). Plasma concentrations of BHB were determined based on the oxidation of $\mathrm{D}$ 3-hydroxybutyrate to acetoacetate by the enzyme 3-hydroxybutyrate dehydrogenase (Cayman Chemical, Ann Arbor, MI). Total cholesterol was measured using commercial enzymatic colorimetric kits (Instrumentation Laboratory s.p.a, Milan, Italy; Biosis, Athens, Greece) based on the method described by Allain et al. (1974). We calculated the ratio of $\alpha$-tocopherol $(\mu \mathrm{mol} / \mathrm{L})$ to cholesterol $(\mu \mathrm{mol} / \mathrm{L})$ multiplied by 1,000 (to provide more meaningful, easily understood numbers) to adjust for changes in lipid transport and stage of lactation (Herdt and Smith, 1996; Qu et al., 2013).

Individual milk samples were collected weekly for 4 weeks postpartum. Samples were analyzed for protein and fat by infrared method using a MilkoScan 133B (Foss Electric, Hillerød, Denmark) calibrated against the Kjeldahl method for protein and the Mojonnier method for fat. SCC were determined using a Fossomatic cell counter (Foss Electric).

We performed statistical analysis with ANOVA using a linear mixed model, considering 2 independent fixed 
Table 1. Daily milk yield and milk composition from the 4 participating farms ${ }^{1}$

\begin{tabular}{lrrrr}
\hline Trait & \multicolumn{1}{c}{ Farm A } & \multicolumn{1}{c}{ Farm B } & \multicolumn{1}{c}{ Farm C } & \multicolumn{1}{c}{ Farm D } \\
\hline Milk yield (L/d) & $45.65 \pm 0.87$ & $46.47 \pm 0.88$ & $38.20 \pm 1.12$ & $39.40 \pm 1.14$ \\
Fat (\%) & $3.59 \pm 0.07$ & $3.14 \pm 0.09$ & $4.15 \pm 0.02$ & $4.16 \pm 0.02$ \\
Protein (\%) & $2.91 \pm 0.03$ & $2.99 \pm 0.04$ & $3.45 \pm 0.03$ & $3.43 \pm 0.03$ \\
Log SCC/mL & $1.60 \pm 0.07$ & $1.49 \pm 0.08$ & $1.96 \pm 0.04$ & $1.86 \pm 0.06$ \\
\hline
\end{tabular}

${ }^{1}$ Farms A and B were the Italian farms and farms C and D were the Greek farms. All values are LSM \pm SEM.

factors: farm and time of sampling. For the fixed factor "time of sampling," 3 measures were repeated for each cow. Cow was considered a random factor nested within farm. We tested several covariance structures: compound symmetry was used for fatty acids and $\mathrm{BHB}$, and first-order autoregressive for $\alpha$-tocopherol, resulting in the smallest Akaike information criterion.

The model used was

$$
Y_{i j k}=\mu+F_{i}+T_{j}+F_{i} \times T_{j}+C_{k(i)}+e_{i j k}
$$

where $Y_{i j k}$ is the individual value for each dependent variable (fatty acids, $\mathrm{BHB}, \alpha$-tocopherol, $\log _{\mathrm{SCC}}$ ); $\mu$ is the overall mean; $F_{i}$ is the fixed effect of farm ( 1 and $2=$ Italian farms and 3 and $4=$ Greek farms); $T_{j}$ is the fixed effect of 3 repeated measures factor "time of sampling" for each cow ( $1=$ dry-off, $2=$ calving, $3=$ $+30 \mathrm{~d}$ of lactation); $C_{k(i)}$ is the random animal effect, nested within farm; and $e_{i j k}$ is the random error assumed to be normally and independently distributed with zero expectation and common variance $\sigma^{2}$. Values in the tables are least squares means (with SEM). We used the Bonferroni test for $P$-values when performing multiple comparisons and assigned significance at an $\alpha$ level of 0.05 unless otherwise noted. All analyses were carried out by PROC MIXED in SAS, version 9.0 (SAS Institute, 2004). To examine relationships between data, we estimated the bivariate correlations of Spearman's rho at each sampling time using the PROC CORR statement in SAS.

Milk yield and milk composition from all 4 farms are presented in Table 1. Milk yield was approximately $20 \%$ higher in the Italian farms than in the Greek farms. As expected, we observed higher levels of fat and protein in the Greek farms. Somatic cell counts were very low in all farms. None of the animals developed symptoms of clinical or subclinical mastitis.

Table 2 shows changes in the concentrations of fatty acids, BHB, and $\alpha$-tocopherol during the periparturient period in dairy cows. Fatty acids were low at the beginning of the dry period. Fatty acid concentrations at calving were 3.3 -fold higher than corresponding values at dry-off. The amount of fatty acids declined by $50 \%$ at 30 d postpartum compared with corresponding values at calving. In contrast, $\mathrm{BHB}$ concentrations were low at dry-off, increased by $27 \%(P<0.05)$ at calving, and continued to increase by another $20 \%$ at $30 \mathrm{~d}$ postpartum. Concentrations of $\alpha$-tocopherol at calving were $50 \%$ lower than the corresponding values at dry-off; concentrations increased in the postpartum period and essentially reached dry-off levels by $30 \mathrm{~d}$ postpartum. Changes in cholesterol and the ratio of $\alpha$-tocopherol to cholesterol followed similar trends to those of $\alpha$-tocopherol alone. The lowest values for both parameters were detected at calving. Cholesterol concentrations and the ratio of $\alpha$-tocopherol to cholesterol were higher at dry-off and $30 \mathrm{~d}$ postpartum than at calving.

Table 3 shows the Spearman's rho correlation coefficients between the concentrations of blood fatty acids, $\mathrm{BHB}$, and $\alpha$-tocopherol before and after adjustment with cholesterol at dry-off, calving, and at $30 \mathrm{~d}$ postpartum. Correlations between fatty acids and BHB at all 3 sampling points were extremely weak $(P=0.186-0.732)$. We found a negative correlation between fatty acids and blood $\alpha$-tocopherol at $30 \mathrm{~d}$ postpartum (rho value $=-0.3 ; P<0.001)$ and a negative correlation that approached significance at dry-off (rho value $=-0.17$;

Table 2. Changes in levels of blood fatty acids, BHB, $\alpha$-tocopherol $(\alpha-T)$, total cholesterol (TC), and the ratio of $\alpha$-T to total cholesterol during the periparturient period in dairy cows ${ }^{1}$

\begin{tabular}{lccccc}
\hline Time of sampling & $\begin{array}{c}\text { Fatty acids } \\
(\mathrm{mmol} / \mathrm{L})\end{array}$ & BHB $(\mathrm{mmol} / \mathrm{L})$ & $\alpha-\mathrm{T}(\mu \mathrm{mol} / \mathrm{L})$ & TC $(\mathrm{mmol} / \mathrm{L})$ & $\begin{array}{c}\alpha-\mathrm{T}(\mu \mathrm{mol} / \mathrm{L}): \mathrm{TC} \\
(\mu \mathrm{mol} / \mathrm{L})\left(\times 10^{3}\right)\end{array}$ \\
\hline Dry-off & $0.155^{\mathrm{a}} \pm 0.017$ & $0.394^{\mathrm{a}} \pm 0.024$ & $8.900^{\mathrm{a}} \pm 0.206$ & $3.898^{\mathrm{a}} \pm 0.099$ & $2.422^{\mathrm{a}} \pm 0.061$ \\
Calving & $0.511^{\mathrm{b}} \pm 0.017$ & $0.512^{\mathrm{b}} \pm 0.024$ & $4.372^{\mathrm{b}} \pm 0.206$ & $2.471^{\mathrm{b}} \pm 0.099$ & $1.863^{\mathrm{b}} \pm 0.062$ \\
30 d postpartum & $0.255^{\mathrm{c}} \pm 0.017$ & $0.620^{\mathrm{c}} \pm 0.024$ & $9.062^{\mathrm{a}} \pm 0.212$ & $3.988^{\mathrm{a}} \pm 0.099$ & $2.361^{\mathrm{a}} \pm 0.063$ \\
\hline
\end{tabular}

${ }^{a-c}$ Means within the same column followed by different letters differ at $P<0.05$.

${ }^{1}$ Dairy cows from 4 herds, 2 of them in Italy and 2 in Greece; all values are LSM \pm SEM. 
Table 3. Spearman's rho correlations between the levels of blood fatty acids, BHB, $\alpha$-tocopherol $(\alpha-T)$, and the ratio of $\alpha-T$ to total cholesterol (TC) during the periparturient period in dairy cows ${ }^{1}$

\begin{tabular}{|c|c|c|c|c|c|c|}
\hline Time & Item & & $\begin{array}{l}\text { Fatty } \\
\text { acids }\end{array}$ & $\mathrm{BHB}$ & $\alpha-T$ & $\alpha-\mathrm{T}: \mathrm{TC}$ \\
\hline Dry-off & $\begin{array}{l}\text { Fatty acids } \\
\text { BHB } \\
\alpha-T \\
\alpha-T: T C\end{array}$ & $\begin{array}{l}\text { Rho } \\
P \text {-value } \\
\text { Rho } \\
P \text {-value } \\
\text { Rho } \\
P \text {-value } \\
\text { Rho } \\
P \text {-value }\end{array}$ & $\begin{array}{c}1 \\
-\end{array}$ & $\begin{array}{l}0.114 \\
\text { NS } \\
1 \\
-\end{array}$ & $\begin{array}{l}-0.169 \\
\text { NS } \\
-0.370 \\
* * * \\
1 \\
-\end{array}$ & $\begin{array}{c}-0.002 \\
\text { NS } \\
-0.352 \\
* * * \\
0.348 \\
* * * \\
1 \\
-\end{array}$ \\
\hline Calving & $\begin{array}{l}\text { Fatty acids } \\
\text { BHB } \\
\alpha-T \\
\alpha-T: T C\end{array}$ & $\begin{array}{l}\text { Rho } \\
P \text {-value } \\
\text { Rho } \\
P \text {-value } \\
\text { Rho } \\
P \text {-value } \\
\text { Rho } \\
P \text {-value }\end{array}$ & 1 & $\begin{array}{l}0.116 \\
\text { NS } \\
1 \\
-\end{array}$ & $\begin{array}{l}-0.084 \\
\text { NS } \\
-0.010 \\
\text { NS } \\
1 \\
-\end{array}$ & $\begin{array}{l}0.053 \\
\text { NS } \\
0.165 \\
\text { NS } \\
0.207 \\
{ }^{*} \\
1 \\
-\end{array}$ \\
\hline $30 \mathrm{~d}$ postpartum & $\begin{array}{l}\text { Fatty acids } \\
\text { BHB } \\
\alpha-T \\
\alpha-T: T C\end{array}$ & $\begin{array}{l}\text { Rho } \\
P \text {-value } \\
\text { Rho } \\
P \text {-value } \\
\text { Rho } \\
P \text {-value } \\
\text { Rho } \\
P \text {-value }\end{array}$ & 1 & $\begin{array}{l}-0.030 \\
\mathrm{NS} \\
1 \\
-\end{array}$ & $\begin{array}{l}-0.300 \\
* * * \\
-0.104 \\
\mathrm{NS} \\
1 \\
-\end{array}$ & $\begin{array}{l}0.028 \\
\text { NS } \\
-0.188 \\
* \\
0.388 \\
* * * \\
1 \\
-\end{array}$ \\
\hline
\end{tabular}

${ }^{1}$ Dairy cows from 4 herds, 2 of them in Italy and 2 in Greece.

*Correlation is significant at $P<0.05$ or ${ }^{* * *} P<0.001$ (2-tailed).

$P=0.06)$. However, both negative correlations became nonsignificant following adjustment of $\alpha$-tocopherol with cholesterol (ratio of $\alpha$-tocopherol to cholesterol). In contrast, we found a correlation between BHB and $\alpha$-tocopherol $(P<0.001)$ before or after adjustment with cholesterol at dry-off. We also found a negative weak correlation between BHB and $\alpha$-tocopherol after adjustment with cholesterol (rho value $=-0.19 ; P<$ $0.05)$ at $30 \mathrm{~d}$ postpartum.

The first finding emerging from the present study is that fatty acid and BHB concentrations are not correlated during the periparturient period. This conclusion is supported by 2 observations. First, BHB and fatty acids followed similar trends in the prepartum period (dry-off vs. calving), even though changes in fatty acids were more pronounced. The 2 parameters followed exactly opposite trends in the postpartum period (calving vs. $30 \mathrm{~d}$ postpartum): fatty acid values declined, and BHB values continued to increase at $30 \mathrm{~d}$ postpartum. Second, we detected a weak correlation $(P$ $>0.05$ ) between fatty acids and BHB (Table 3). Thus, changes in the concentrations of one metabolite should not be taken to automatically suggest corresponding changes in the concentration of the other. Our data have many similarities with those of McCarthy et al. (2015), which had the advantage of more observations and much more frequent sampling. However, all their experiments were performed in North America, where cows are likely to experience higher levels of oxidative stress than cows in European countries (Allison and Laven, 2000), particularly countries in the Mediterranean region. Even though we have confirmed earlier findings with the present study, the fact that our data were obtained from a different environment and production system makes them novel.

The second finding that was significant negative correlations between fatty acids and $\alpha$-tocopherol at dryoff and $30 \mathrm{~d}$ postpartum exist. However, the fact that these correlations disappeared following adjustment of $\alpha$-tocopherol with cholesterol indicates that they were simply a reflection of changes in lipid transport. Furthermore, we found strong negative correlations at dry-off (rho values $=-0.352$ and $-0.370 ; P<0.001$ ) between BHB and $\alpha$-tocopherol before and after adjustment with cholesterol. We also found a weak but significant correlation $(P<0.05)$ between BHB and the ratio of $\alpha$-tocopherol to cholesterol at $30 \mathrm{~d}$ postpartum. It is interesting to observe that $\alpha$-tocopherol was negatively correlated with BHB at dry-off but that those correlations were nonsignificant or extremely weak at calving and $30 \mathrm{~d}$ postpartum. It seems that the association between $\alpha$-tocopherol and BHB is more prominent at dry-off and less prominent at calving or postpartum. This might be related to the fact that 
postpartum hyperketonemia was essentially nonexistent in all 4 participating farms. The physiological basis for the negative correlations between $\alpha$-tocopherol and BHB is not known and should not be taken to imply a cause-effect relationship. Previous research has revealed a direct link between $\alpha$-tocopherol and incidence of mastitis and retained placenta, and the physiological basis of the link between vitamin $\mathrm{E}$ and mastitis is the relationship between $\alpha$-tocopherol and proper immune function (Politis, 2012). Our results have certain similarities with those of Qu et al. (2014), who reported that elevated BHB concentrations before calving coincided with low $\alpha$-tocopherol concentrations. Furthermore, they reported that this inverse relationship held only in the prepartum period and served as a potential risk indicator for retained placenta.

To date, the prevalent view is that vitamin E status and ketosis are unrelated. However, the negative correlations between BHB and $\alpha$-tocopherol certainly open the door to more careful investigations of the effects of vitamin $\mathrm{E}$ on liver function in dairy cows. In addition to the well-documented link between vitamin E status and immune function, there may be a link between vitamin E status and metabolic function at the level of the liver in dairy cows, similar to that in rodents and humans. In vivo observations suggest a possible role for oxidative stress and liver function in dairy cows. Mudron et al. (1999) showed that cows with fatty liver have lower antioxidant status and higher hepatic lipid peroxide concentrations than healthy cows. Bouwstra et al. (2008) have reported that vitamin $\mathrm{E}$ has a role in recovery from parturition-related oxidative stress in periparturient heifers. Their suggestion that vitamin E reduces oxidative damage in the liver provides indirect support for the concept we propose. The possibility that $\alpha$-tocopherol affects liver function is one side of the story; it is also possible that liver function affects $\alpha$-tocopherol secretion and transport in the liver. The latter concept is supported by the work of Mudron et al. (1997), who reported that cows with fatty liver had lower plasma $\alpha$-tocopherol concentrations but normal or higher $\alpha$-tocopherol concentrations in the liver. Thus, in cows with fatty liver, $\alpha$-tocopherol transport out of the liver may be impaired.

Indirect support for the concept that fatty acids and $\alpha$-tocopherol are negatively correlated comes from the work of Pinotti et al. (2003) in an experiment involving choline supplementation in dairy cows. They found that transition cows, receiving rumen-protected choline, had lower plasma fatty acid concentrations and higher $\alpha$-tocopherol around calving than controls, and they suggested that this finding could be related to more efficient liver function.
The present study documents a weak nonsignificant correlation between fatty acids and BHB during the periparturient period in dairy cows. Negative correlations between fatty acids and $\alpha$-tocopherol were mainly a reflection of changes in lipid transport. The most interesting finding of our correlation analysis was the relatively strong correlation between BHB and $\alpha$-tocopherol at dry-off. Future studies will examine whether, in addition to the well-documented link between vitamin E and the immune system in dairy cows, we may have forgotten to examine the effects of vitamin $\mathrm{E}$ on the metabolic function of the liver, similar to that in rodents and humans.

\section{ACKNOWLEDGMENTS}

The research performed in Italy was financially supported by ASL-MILANO2 (Milan, Italy). The authors thank Azienda Agricola Mapelli Ferdinando Umberto (Milan, Italy) and Società Agricola Passoni Antonio \& C. S.S-Bellinzago Lombardo (Milan, Italy), whose farms were used in this study. The authors are grateful to the reviewers, whose comments helped us immensely in improving the manuscript.

\section{REFERENCES}

Allain, C. C., L. S. Poon, C. S. Chan, W. Richmond, and P. C. Fu. 1974. Enzymatic determination of total serum cholesterol. Clin. Chem. 20:470-475.

Allison, R. D., and R. A. Laven. 2000. Effect of vitamin E supplementation on the health and fertility of dairy cows: A review. Vet. Rec. 147:703-708.

Baldi, A., G. Savoini, L. Pinotti, E. Monfardini, F. Cheli, and V. Dell'Orto. 2000. Effects of vitamin E and different energy sources on vitamin E status, milk quality and reproduction in transition cows. J. Vet. Med. A Physiol. Pathol. Clin. Med. 47:599-608.

Bertoni, G., A. Minuti, and E. Trevisi. 2015. Immune system, inflammation and nutrition in dairy cattle. Anim. Prod. Sci. 55:943-948.

Bouwstra, R. J., R. M. A. Goselink, P. Dobbelaar, M. Nielen, J. R. Newbold, and T. van Werven. 2008. The relationship between oxidative damage and vitamin $\mathrm{E}$ concentration in blood, milk and liver tissue from vitamin E supplemented and nonsupplemented periparturient heifers. J. Dairy Sci. 91:977-987.

Bradford, B. J., K. Yuan, J. K. Farney, L. K. Mamedova, and A. J. Carpenter. 2015. Invited review: Inflammation during the transition to lactation: New adventures with an old flame. J. Dairy Sci. 98:6631-6650.

Chapinal, N., M. Carson, T. F. Duffield, M. Capel, S. Godden, M. Overton, J. E. Santos, and S. J. LeBlanc. 2011. The association of serum metabolites with clinical disease during the transition period. J. Dairy Sci. 94:4897-4903.

Duffield, T. F., K. D. Lissemore, B. W. McBride, and K. E. Leslie. 2009. Impact of hyperketonemia in early lactation dairy cows on health and production. J. Dairy Sci. 92:571-580.

Herdt, T. H., and J. C. Smith. 1996. Blood-lipid and lactation stage factors affecting serum vitamin $\mathrm{E}$ concentrations and vitamin $\mathrm{E}$ cholesterol ratios in dairy cattle. J. Vet. Diagn. Invest. 8:228-232.

Konigsson, K., G. Savoini, N. Govoni, G. Invernizzi, A. Prandi, H. Kindahl, and M. C. Veronesi. 2008. Energy balance, leptin, NEFA and IGF-I plasma concentrations and resumption of post partum 
ovarian activity in Swedish Red and White breed cows. Acta Vet. Scand. 50:3.

LeBlanc, S. 2010. Monitoring metabolic health of dairy cattle in the transition period. J. Reprod. Dev. 56(Suppl):S29-S35.

Mao, G., G. A. Kraus, I. Kim, M. E. Spurlock, T. B. Bailey, Q. Zhang, and D. C. Beitz. 2010. A mitochondria-targeted vitamin E derivative decreases hepatic oxidative stress and inhibits fat deposition in mice. J. Nutr. 140:1425-1431.

McArt, J. A., D. V. Nydam, and G. R. Oetzel. 2012. Epidemiology of subclinical ketosis in early lactation dairy cattle. J. Dairy Sci. 95:5056-5066.

McArt, J. A., D. V. Nydam, G. R. Oetzel, T. R. Overton, and P. A. Ospina. 2013. Elevated non-esterified fatty acids and betahydroxybutyrate and their association with transition dairy cow performance. Vet. J. 198:560-570.

McCarthy, M. M., S. Mann, D. V. Nydam, T. R. Overton, and J. A. McArt. 2015. Short communication: concentrations of nonesterified fatty acids and beta-hydroxybutyrate in dairy cows are not well correlated during the transition period. J. Dairy Sci. 98:62846290.

Mudron, P., J. Rehage, K. Qualmann, H. P. Sallmann, and H. Scholz. 1999. A study of lipid peroxidation and vitamin $\mathrm{E}$ in dairy cows with hepatic insufficiency. Zentralbl. Veterinarmed. A 46:219-224.

Mudron, P., J. Rehage, H. P. Sallman, M. Mertens, H. Scholz, and G. Kovac. 1997. Plasma and liver $\alpha$-tocopherol in dairy cows with left abomasal displacement and fatty liver. Zentralbl. Veterinarmed. A 44:91-97.

Ospina, P. A., D. V. Nydam, T. Stokol, and T. R. Overton. 2010a. Associations of elevated nonesterified fatty acids and beta-hydroxybutyrate concentrations with early lactation reproductive performance and milk production in transition dairy cattle in the northeastern United States. J. Dairy Sci. 93:1596-1603.

Ospina, P. A., D. V. Nydam, T. Stokol, and T. R. Overton. 2010b. Evaluation of nonesterified fatty acids and beta-hydroxybutyrate in transition dairy cattle in the northeastern United States:
Critical thresholds for prediction of clinical diseases. J. Dairy Sci 93:546-554.

Pinotti, L., A. Baldi, I. Politis, R. Rebucci, L. Sangalli, and V. Dell'Orto. 2003. Rumen-protected choline administration to transition cows: Effects on milk production and vitamin E status. J. Vet. Med. A Physiol. Pathol. Clin. Med. 50:18-21.

Politis, I. 2012. Reevaluation of vitamin E supplementation of dairy cows: Bioavailability, animal health and milk quality. Animal 6:1427-1434.

Qu, Y., N. A. Fadden, M. G. Traber, and G. Bobe. 2014. Potential risk indicators of retained placenta and other diseases in multiparous cows. J. Dairy Sci. 97:4151-4165.

Qu, Y., K. Lytle, M. G. Traber, and G. Bole. 2013. Depleted serum vitamin E concentrations precede left displaced abomasum in earlylactation dairy cows. J. Dairy Sci. 96:3012-3022.

Rinella, M. E. 2015. Nonalcoholic fatty liver disease: A systematic review. JAMA 313:2263-2273.

Sakaguchi, S., and S. Furusawa. 2006. Oxidative stress and septic shock: Metabolic aspects of oxygen-derived free radicals generated in the liver during endotoxemia. FEMS Immunol. Med. Microbiol. $47: 167-177$.

SAS Institute. 2004. SAS User's Guide: Statistics. Version 9 ed. SAS Institute, Cary, NC.

Sato, K., M. Gosho, T. Yamamoto, Y. Kobayashi, N. Ishii, T. Ohashi, Y. Nakade, K. Ito, Y. Fukuzawa, and M. Yoneda. 2015. Vitamin E has a beneficial effect on nonalcoholic fatty liver disease: A metaanalysis of randomized controlled trials. Nutrition 31:923-930.

Stella, A. V., R. Paratte, L. Valnegri, G. Cigalino, G. Soncini, E. Chevaux, V. Dell'Orto, and G. Savoini. 2007. Effect of administration of live Saccharomyces cerevisiae on milk production, milk composition, blood metabolites, and faecal flora in early lactating dairy goats. Small Rumin. Res. 67:7-13.

Suthar, V. S., J. Canelas-Raposo, A. Deniz, and W. Heuwieser. 2013 Prevalence of subclinical ketosis and relationships with postpartum diseases in European dairy cows. J. Dairy Sci. 96:2925-2938. 